\title{
Treatment adherence and frailty syndrome in hypertensive older adults
}

\author{
Adesão ao tratamento e síndrome da fragilidade em idosos hipertensos \\ Adherencia al tratamiento y síndrome de fragilidad en adultos mayores hipertensos
}

How to cite this article:

Silva LM, Souza AC, Fhon JRS, Rodrigues RAP. Treatment adherence and frailty syndrome in hypertensive older adults. Rev Esc Enferm USP. 2020;54:e03590. doi: https://doi.org/10.1590/S1980-220X2018048903590

\section{Luípa Michele Silva ${ }^{1,2}$ \\ Ana Carolina de Souza ${ }^{2}$ \\ Jack Roberto Silva Fhon ${ }^{2}$ \\ Rosalina Aparecida Partezani Rodrigues $^{2}$}

${ }^{1}$ Universidade Federal de Goiás Regional Catalão/Universidade Federal de Catalão em implantação, Departamento de Enfermagem, Catalão, GO, Brazil

${ }^{2}$ Universidade de São Paulo, Escola de Enfermagem de Ribeirão Preto, Ribeirão Preto, SP, Brazil.

\begin{abstract}
Objective: To analyze the association between adherence to antihypertensive treatment and frailty syndrome in hypertensive older adults. Method: A descriptive, cross-sectional study with a quantitative approach with older adults. The data collection took place between November 2017 and March 2018, evaluating sociodemographic information, adherence to antihypertensive treatment, lifestyle and frailty through the Edmonton Frail Scale. The Kruskal-Wallis test and the Chi-squared test were used for data analysis, considering a $95 \%$ confidence interval and a significance level of $\mathrm{p}<0.05$. Results: There were 193 older adults who participated in the study. The average age was 80.94 (sd \pm 7.17 ) years, with a predominance of females (72\%) and widows (43.5\%). The factors which were associated with adherence to treatment were diastolic blood pressure, education and the time that the older adult had smoked $(\mathrm{p}<0.05)$. Frailty was not associated with treatment adherence levels $(p=0.095)$. Conclusion: There was no association between frailty scores and control of arterial hypertension; however, adequate monitoring and nursing care are essential in assessing adherence to treatment in order to reduce the aggravations of the disease and frailty syndrome development.
\end{abstract}

DESCRIPTORS

Aged; Hypertension; Medication Adherence; Frailty; Geriatric Nursing.
Corresponding author:

Luípa Michele Silva

Campus I - Bloco M - Sala 156

Av. Dr. Lamartine Pinto de Avelar, 1120

CEP 75704-020 - Catalão, GO, Brazil

luipams@gmail.com
Received: 11/05/2018

Approved: 09/30/2019 


\section{INTRODUCTION}

The increase in the older adult population in the world and in Brazil directly affects the public health system, as pathological conditions can compromise the vascular system over the course of the aging process, thereby making this population more susceptible to morbidities such as systemic arterial hypertension $(\mathrm{SAH})^{(1)}$.

This disease is currently estimated as one of the main global public health problems, as it has a high prevalence and low control rates, resulting in significant numbers of cardiovascular morbidity and mortality ${ }^{(2)}$. It is estimated that $25 \%$ of the adult population in Brazil is diagnosed with $\mathrm{SAH}$, and it is estimated that its prevalence will be $40 \%$ in $2025^{(3)}$. A Brazilian population-based study estimates that the prevalence among older adults is $75.6 \%$ (95\% CI $=71.1-77.9)^{(4)}$.

The association between aging and the hypertension prevalence is direct and linear, as it is related to the increase in life expectancy of the population ${ }^{(5)}$. In a meta-analysis study carried out with older adults from urban areas in Brazil, the researchers estimated arterial hypertension prevalence of $68 \%{ }^{(6)}$. In addition to age, race, gender, genetic predisposition, stress, overweight, obesity, and lifestyle habits considered unhealthy such as physical inactivity and excessive alcohol consumption, smoking and excessive salt consumption are also considered as risk factors or predictors of the disease ${ }^{(5)}$.

Non-adherence or inadequate adherence to drug treatments are the main causes of ineffective therapy in Brazil and worldwide ${ }^{(1)}$. The best control of hypertension aims to decrease the incidence of disease and prevent a substantial number of deaths. In this sense, Nursing has a fundamental role in care practice with the use of nursing diagnosis, constituting a tool which directs actions and the care plan with educational actions as the main intervention strategy to increase adherence to antihypertensive treatment ${ }^{(7)}$.

Adherence to antihypertensive treatment in older adults considerably reduces the risk of stroke, controls heart failure and reduces mortality from cardiovascular diseases ${ }^{(8)}$. According to the World Health Organization, both the diagnosis and treatment of arterial hypertension have been challenging in older adults, as they are patients who need careful pharmacotherapy; ideally, monotherapy with low doses of antihypertensive medication ${ }^{(9)}$.

Adherence and medication intake on a regular basis are paramount for effective therapy in older adults; therefore, it is necessary for the older adults to get involved in their treatment, understand the objectives of the adopted therapy and feel good during the care process ${ }^{(10)}$. Some obstacles found in order for drug treatment to be effective are "forgotten" doses, economic situation, side effects of drugs, the presence of comorbidities, advanced age and being considered frail ${ }^{(11)}$.

According to the consensus proposed by a group of researchers, a frail older adult is one who presents a decrease in strength and resistance, as well as a decline in physiological functions, making them vulnerable and consequently having increased dependence and/or death ${ }^{(12)}$. In this sense, frailty can be understood as a multidimensional syndrome of complex etiology, requiring an assessment using instruments which have a holistic view of older adults, being determined or modified by biological, psychological and social factors which generate a condition of a multifactorial nature, uncomfortable and dynamic according to the individual's history or life course $\mathrm{i}^{(13-15)}$.

The following criteria should be considered for a frail older adult: five or more diseases, using at least five medications, presenting impaired physical mobility, having a history of falls and recurrent hospitalizations, precarious family relationships, cognitive impairment and functional dependence ${ }^{(16)}$.

The frailty syndrome in older adults has been widely discussed in recent years, since it affects $15 \%$ to $20 \%$ of these people aged over 60 , and $30 \%$ of those over 80 years old ${ }^{(17)}$. Moreover, the presence of the syndrome has been considered as a causative and prognostic factor of cardiovascular diseases, with the estimated prevalence being between 25 to $50 \%$ of older adults with heart problems being frail and $21 \%$ having low level adherence, while only $12.3 \%$ of older adults in the non-frail group have low level adherence ${ }^{(18)}$.

Assessing the association of frailty and adherence to antihypertensive treatment can be the first step to understand whether there is an interaction between them, and it can ultimately optimize the treatment of existing hypertension and establish therapeutic goals in people who are frail. However, studies in Brazil which demonstrate the relationship between frail older adults, hypertensive disease and adherence to pharmacological treatment in a way which would enable thinking about risk factors and encouraging means for interventions in the frailty syndrome are still scarce.

In view of the problem presented above, this investigation is justified due to the high prevalence of $\mathrm{SAH}$ in older adults and the possible relationship between adherence and the presence of frailty which requires attention from professionals working in health services. To this end, the aim of the study was to analyze the association between adherence to antihypertensive treatment and the frailty syndrome in hypertensive older adults.

\section{METHOD}

\section{StUdi DESIGN}

This is a descriptive, cross-sectional study with a quantitative approach.

\section{Population}

The study population consisted of older adults aged 65 or over living in the urban area of the city of Ribeirão Preto, SP, Brazil.

The sample was defined in the first phase of this investigation in 2007, which was a funded project. However, this study composes the third stage of this research in which the older adults interviewed in 2017/2018 were evaluated, thereby totaling 262 of the initial sample. 
The research sampling process was followed in all stages, being probabilistic by a two-stage conglomerate, in which 30 census sectors were initially drawn from the 600 sectors existing in the municipality. A fixed number of households were subsequently visited in the second stage, which guaranteed self-weighting in the sample. There were 515 older adults selected as a way to prevent refusals, which resulted in the expected rate of $80 \%$.

As this is a follow-up study with losses and deaths, the maintained sample was 262 older adults, among whom 193 (73.3\%) met the established inclusion criterion, which was to have a medical diagnosis of systemic arterial hypertension.

\section{Data collection}

Data collection was carried out between the months of December 2017 and March 2018 at the participants' homes through a structured interview conducted by undergraduate and graduate students previously trained by the project coordinator, and using a questionnaire with validated instruments. The interviews lasted an average of 50 minutes.

The Morisky Medication Adherence Scale (MMAS), validated in Brazil $^{(19)}$, was used to evaluate adherence to hypertensive drug treatment, which consisted of the following questions: 1) Do you sometimes have problems remembering to take your medication? 2) Do you sometimes neglect to take your medication? 3) When you are feeling better, do you sometimes stop taking your medication? 4) If you feel worse when taking the medication, do you sometimes stop taking it? Good adherence was considered when all responses were negative and low adherence when two or more responses were affirmative on the MMAS instrument.

Adherence was also assessed based on manual pill counting to verify the degree of coincidence between the amount of pills used by the older adult in a given time interval and the amount which should have been used in that same time interval (according to the prescribed therapeutic regimen). Thus, manual counting of the pills which were on the chart of each medication was performed and compared with the prescribed therapeutic regimen ${ }^{(20)}$.

The calculation used was:

Degree of agreement between used and prescribed pills = (NPA - NPR) x100/NCP, in which:

$\mathrm{NPA}=$ number of pills acquired by the patient in the last visit.

$\mathrm{NPR}=$ number of pills remaining in the package.

$\mathrm{NCP}=$ number of pills which should have been consumed according to the prescription in the interval between acquisition and counting the pills.

It is reported that the calculation was made separately for each older adult who used more than one medication.

The MMSA score was taken into account for creating the adhesion variable: Adherent - no positive response; Moderate adherence -1 to 2 positive responses; and Low adherence -3 to 4 positive responses. Thus, the following was obtained from the discrepancy and from this score: Optimal adhesion - no discrepancy and adherent on the Morisky; Good adherence - no discrepancy and moderate adherence or discrepancy and adherent on the Morisky;
Regular adherence - presenting a discrepancy and moderate adherence on the Morisky or no discrepancy and low adherence; and Poor adherence - presenting a discrepancy and low adherence on the Morisky. A weighted adherence (average of the scores) was created based on the adherence of each medication, ranging from 0 to $100 \%$ for each participant, which resulted in the following values: above $75 \%$, good; 74 to $50 \%$, regular; below $50 \%$, bad ${ }^{(20)}$.

The frailty assessment was performed by the Edmonton Frail Scale ${ }^{(15)}$, validated for the Portuguese language ${ }^{(21)}$. This scale has nine domains: cognition, general health status, functional independence, social support, medication use, nutrition, mood, continence and functional performance ${ }^{(15,21)}$. The scale score ${ }^{(15,21)}$ varies from 0 to 17 points, with the maximum value indicating a higher level of frailty.

The independent variables used for the purposes of analysis were: gender (male, female), self-reported age (years), marital status (single, married, widowed, divorced), years of education, total self-reported diseases, income (in Brazilian currency Reais), alcohol use (amount ingested per week or month) and tobacco use (yes or no), and for how long they have used/consumed it.

Blood pressure was measured three times according to the recommendations of the VII Brazilian Guideline for Arterial Hypertension using a calibrated aneroid sphygmomanometer (Techline BP-1305 Digital Arm Pressure Meter), with the individual sitting and at rest for at least fifteen minutes. Three systolic (SBP) and diastolic (DBP) blood pressure measurements were verified, with an interval of one to two minutes, thus obtaining the means for each of these variables ${ }^{(5)}$.

\section{DATA ANALYSIS AND PROCESSING}

An electronic spreadsheet was created in the Microsoft Excel $^{\oplus}$ program to elaborate the database, in which double entry typing was performed. The data were imported into a statistical program to perform the descriptive analysis. Quantitative variables were analyzed using central tendency (mean and median) and dispersion (sd = standard deviation) measures and categorical variables in absolute and relative frequency. The Kruskal-Wallis test was used to analyze adherence with three groups and independent variables, and the Chi-squared test was used to compare adherence and variables related to the older adults' lifestyles, such as the use of tobacco (tobacco), the performance of some type of physical activity and the intake of alcoholic beverages. A 95\% confidence interval and significance level of $p<0.05$ were considered for both tests.

\section{ETHICAL ASPECTS}

The research project was approved by the Research Ethics Committee of the Ribeirão Preto School of Nursing at the Universidade de São Paulo under Protocol No. 089/2017, following the recommendations in Resolution 466/2012 of the National Health Council. The older adults signed an Informed Consent Form in two copies. 


\section{RESULTS}

There were 193 older adults who participated in the study. The results showed that the older adults in the study had an average age of $80.94( \pm 7.17)$ years, with a minimum of 65 and a maximum of 97 years. The majority were female (72\%), widows (43.5\%), who use health insurance (49.2\%) and also the Unified Health System (SUS - Sistema Único de Saúde) (48.2). The average years of education of these older adults was 5.28 years ( $\mathrm{SD} \pm 4.87$ years). The monthly income in minimum monthly salaries ranged from one $(18.1 \%)$ to more than $10(4.7 \%)$, with the highest concentration between three and five salaries (33.2\%). The number of self-reported diseases was an average of $6.03(\mathrm{SD}=3.84)$. Only $9.3 \%$ of the older adults used self-medication, and the majority (57.5\%) showed good adherence to antihypertensive treatment (Table 1).

Table 1 - Characterization of hypertensive older adults who use antihypertensive drugs - Ribeirão Preto, SP, Brazil, 2017-2018.

\begin{tabular}{lccccc}
\hline $\begin{array}{l}\text { Sociodemographic } \\
\text { variables }\end{array}$ & $\mathbf{n}$ & $\%$ & Mean (sd) & Min & Max \\
\hline Age (years) & & & $80.94(7.17)$ & 65 & 97 \\
\hline Education (years of study) & & & $5.28(4.87)$ & 0 & 22 \\
\hline Total self-reported diseases & & & $6.03(3.84)$ & 1 & 18 \\
\hline Gender & 54 & 28.0 & & & \\
Male & 139 & 72.0 & & & \\
Female & & & & & \\
\hline Civil status & 16 & 8.3 & & & \\
Single & 77 & 39.9 & & & \\
Married & 14 & 7.3 & & & \\
Divorced/Separated & 84 & 43.5 & & & \\
Widowed & 2 & 1.0 & & & \\
Other & & & & & \\
\hline
\end{tabular}

Monthly income of the older adult (in minimum monthly salaries)

\begin{tabular}{lcc} 
Up to one & 35 & 18.1 \\
02 & 51 & 26.4 \\
03 to 05 & 64 & 33.2 \\
06 to 09 & 30 & 15.5 \\
More than 10 & 9 & 4.7 \\
Did not know or did not & 4 & 2.1 \\
respond & & \\
\hline Health services & 93 & 48.2 \\
SUS & 95 & 49.2 \\
Health Insurance & 2 & 1.0 \\
Private & 3 & 1.6 \\
Other & & \\
\hline Self-medication & 18 & 9.3 \\
Yes & 175 & 90.7 \\
No & & \\
\hline Adhesion & 111 & 57.5 \\
Good & 65 & 33.7 \\
Regular & 17 & 8.8 \\
Bad &
\end{tabular}

When the association between lifestyle habits was verified, such as the use of tobacco (tobacco), the performance of some type of activity and the consumption of alcoholic beverages, with the adherence to antihypertensive treatment by the older adult, there was no statistically significant association (Table 2).
Table 2 - Association between gender and life habits and adherence to antihypertensive treatment of hypertensive older adults - Ribeirão Preto, SP, Brazil, 2017-2018.

\begin{tabular}{|c|c|c|c|c|c|c|c|}
\hline \multirow{3}{*}{ Variables } & \multicolumn{6}{|c|}{ Adhesion } & \multirow{3}{*}{$\mathbf{p}^{*}$} \\
\hline & \multicolumn{2}{|c|}{ Good } & \multicolumn{2}{|c|}{ Regular } & \multicolumn{2}{|c|}{ Bad } & \\
\hline & $\mathbf{n}$ & $\%$ & $\mathbf{n}$ & $\%$ & $\mathbf{n}$ & $\%$ & \\
\hline \multicolumn{8}{|l|}{ Gender } \\
\hline Male & 29 & 53.7 & 20 & 37.0 & 5 & 9.3 & 0.573 \\
\hline Female & 82 & 59.0 & 45 & 32.4 & 12 & 8.6 & \\
\hline \multicolumn{8}{|l|}{ Smoking (Tobacco) } \\
\hline Yes & 6 & 46.2 & 5 & 38.5 & 2 & 15.4 & 0.579 \\
\hline No & 105 & 58.3 & 60 & 33.3 & 15 & 8.3 & \\
\hline \multicolumn{8}{|c|}{ Perform some type of physical activity } \\
\hline No & 89 & 58.2 & 50 & 32.7 & 14 & 9.2 & 0.830 \\
\hline Yes & 22 & 55.0 & 15 & 37.5 & 3 & 7.5 & \\
\hline \multicolumn{8}{|l|}{ Alcohol consumption } \\
\hline Never & 90 & 59.6 & 51 & 33.8 & 10 & 6.6 & \\
\hline Once a month & 12 & 48.0 & 9 & 36.0 & 4 & 16.0 & \\
\hline $\begin{array}{l}\text { Two to four times a } \\
\text { month }\end{array}$ & 5 & 55.6 & 3 & 33.3 & 1 & 11.1 & 0.123 \\
\hline $\begin{array}{l}\text { Two to three times a } \\
\text { week }\end{array}$ & 2 & 50.0 & 2 & 50.0 & 0 & 0 & \\
\hline $\begin{array}{l}\text { Four or more times } \\
\text { a week }\end{array}$ & 2 & 50.0 & 0 & 0 & 2 & 50.0 & \\
\hline
\end{tabular}

hi-squared test.

It was observed that there was a statistically significant association between the mean diastolic blood pressure and adherence to antihypertensive medication, with the DBP being lower in older adults with good adherence $(\mathrm{p}<0.05$, 70.95 vs 80.65 ). In the relationship between years of education and adherence to drug treatment, the older adults who showed good adherence had a higher average of years in which they had attended school ( $\mathrm{p}<0.05,5.85$ vs 2.94$)$. Moreover, the time that the individual smoked also showed a statistically significant relationship with adherence, as older adults who smoked for less time had good adherence to treatment ( $\mathrm{p}<0.05,17.05$ vs 18.86$)$ (Table 3$)$.

No statistical significance was identified when analyzing the frailty scores and their relationship with the results of the older adults' adherence to antihypertensive treatment, demonstrating that there was no association between frailty and adherence of the hypertensive older adult to antihypertensive treatment, according to the Table 3.

Table 3 - Association between factors which interfere with adherence and adherence to antihypertensive treatment - Ribeirão Preto, SP, Brazil, 2017-2018.

\begin{tabular}{lcccc}
\hline \multirow{2}{*}{ Variables } & \multicolumn{3}{c}{ Adhesion } & \multirow{2}{*}{$\boldsymbol{p}^{*}$} \\
\cline { 2 - 4 } & Good (sd) & Regular (sd) & Bad (sd) & \\
\hline $\begin{array}{l}\text { Systolic Blood } \\
\text { Pressure }\end{array}$ & $142.52(22.67) 140.38(22.30) 155.78(30.56)$ & 0.271 \\
$\begin{array}{l}\text { Diastolic Blood } \\
\text { Pressure }\end{array}$ & $70.95(11.34)$ & $73.39(11.13)$ & $80.64(14.27)$ & 0.032 \\
$\begin{array}{l}\text { Education } \\
\begin{array}{l}\text { Self-reported } \\
\text { diseases (Total) }\end{array}\end{array}$ & $5.85(5.08)$ & $4.92(4.60)$ & $2.94(3.75)$ & 0.011 \\
$\begin{array}{l}\text { Smoking time } \\
\text { (Years) }\end{array}$ & $17.05(20.74)$ & $32.19(20.10)$ & $18.86(5.55)$ & 0.035 \\
Frailty score & $5.50(3.12)$ & $6.12(2.35)$ & $6.82(2.878)$ & 0.095 \\
\hline * Kruskal-Wallis test. & & & & \\
\hline
\end{tabular}




\section{DISCUSSION}

There was a good adherence to antihypertensive treatment in the study population, and the associated factors were education and the duration of tobacco use. However, there was no association between the frailty score and adherence to this treatment.

The prevalence of adherence to drug treatment in the present study was $57.5 \%$, being higher than that found in Taiwanese older adults at a medical center undergoing dialysis treatment ${ }^{(22)}$, and in Cameroonian adults and older adults $^{(23)}$. However, it was lower than the data from an investigation carried out in Vitória, Espírito Santo state, Brazil, which was $73.3 \%{ }^{(24)}$.

Another study showed that the percentage of people over 55 years old in New York who adhered to antihypertensive treatment according to the Morisky scale was only $18.8 \%$, being well below that found in this investigation $^{(11)}$. The difficulty in comparing the data is that studies involving hypertensive patients, whether in Brazil or in other countries, involve participants over the age of 55. The World Health Organization recommends $80 \%$ adherence to antihypertensive treatment ${ }^{(9)}$. Thus, it is evident from all studies that there is still a need to work on adherence in older adult patients to avoid worsening the clinical condition and problems, such as decompensation of arterial hypertension or of other controlled conditions.

The results among the older adults showed that there was no significant difference between men and women regarding adherence to antihypertensive treatment. Worldwide indices indicate that the difference in the prevalence of arterial hypertension between the genders is small ${ }^{(9)}$; however, women seem to have more satisfactory adherence when compared to men in drug treatments ${ }^{(25)}$.

Good adherence depends on how the older adults view the treatment. Something that was consensus in this study and in the international data was the use of methods which depend on involving the older adult during treatment, on their understanding of how the process will occur and on their general well-being. Authors in Italy found that failure to adhere to treatment is due to missed doses because of adverse treatment effects, financial considerations, advancing age, the presence of concomitant illnesses and the onset of frailty syndrome ${ }^{(10)}$.

Non-adherence to drug treatment in Brazil is related to unemployment, low income, tobacco use, decreased or lack of physical activity, and health conditions through the increase in the number of chronic diseases and medical appointments in last 12 months ${ }^{(26)}$.

In this study, it was found that education was associated with adherence to treatment, corroborating with research data from Poland ${ }^{(11)}$ in which the influence of the frailty syndrome on medication adherence in older adults with hypertension showed that high education is a predictor for good adherence. The same study points out that the presence of diseases negatively affected adherence, as well as the fact of living alone, the lack of social support, the death of a partner, divorce and the traumatic event.
A population-based study in Brazil showed an association between adherence and education ${ }^{(26)}$, corroborating the findings of the present study. For Ethiopian researchers ${ }^{(27)}$, education is related to the understanding that the older adults have about their diagnosis and the importance of treating the disease, as prescribed by the physician.

A decrease in consumption was identified regarding the time the participant smoked cigarettes, improving adherence to hypertensive treatment, differing from the findings of Vitória-ES ${ }^{(24)}$, which showed that both the use of tobacco and alcoholic beverage consumption did not interfere in adherence. It is important to note that smoking is among the risk factors listed by the VII Brazilian Guideline for Hypertension in the control and prevention of arterial hypertension ${ }^{(5)}$.

Likewise, it was found that the diastolic blood pressure measurement was associated with adherence to treatment. Research on the self-reported hypertension of the Brazilian population showed that drug monotherapy is not enough to decrease blood pressure levels in 2/3 of the cases; in addition, the older adults need combination therapy for adequate control of systolic $\mathrm{BP}^{(28)}$. Such results corroborate the data of the present study, since the older adults with good adherence have lower diastolic BP values and maintenance of systolic $\mathrm{BP}$ values.

An integrative review on adherence to pharmacological treatment in hypertensive older adults pointed out that the values of systolic blood pressure are below $140 \mathrm{mmHg}$ and $90 \mathrm{mmHg}$ for diastolic blood pressure when they adhere to treatment ${ }^{(29)}$. These findings differ from those found in the study herein, but can be explained due to existing research in Brazil and in other countries which have assessed the adherence of older adult hypertensive patients through different methods and populations, making it difficult to compare the findings.

Research carried out in Ceará state with Primary Care users who are monitored by the Hiperdia program shows that even with the SAH diagnosis and treatment, only $25 \%$ of users maintain pressure levels in a desirable way. Further, the proportion of users with $\mathrm{BP}<140 \times 90 \mathrm{mmHg}$ after starting treatment varied between $6 \%$ and $25 \%$, making the low adherence to treatment from the lack of pressure control evident ${ }^{(30)}$. The older adults in the present study with better blood pressure, especially diastolic, had good adherence to treatment.

According to the VII Brazilian Guideline for Hypertension, it is indicated that the recommended BP for hypertensive older adults under the age of 80 is $<145 / 85$ $\mathrm{mmHg}$. Ideally, the older adult should adhere to treatment to avoid an increase in cardiovascular risk and non-pharmacological treatment should be implemented in association with pharmacological treatment in all hypertension stages and when the patient has a BP of 135-139/85-89 $\mathrm{mmHg}^{(5)}$.

Regarding the frailty syndrome, there was no association with adherence to treatment, but clinically the lack of adherence to prescription drugs reduces the benefits of therapy and can decrease therapeutic efficacy ${ }^{(11)}$. International authors reinforce this importance by stating 
that non-adherence corresponds to $30 \%$ to $50 \%$ of failures in the treatment of older adults ${ }^{(26)}$.

In a study in Taiwan ${ }^{(22)}$, the best adherence to treatment was related to frail patients with advanced age, as they are more attentive to their health and more compliant with the prescribed treatments. According to researchers from Ethiopia $^{(27)}$, developed and developing countries have better healthcare and differentiated access to health facilities, constituting elements which positively affect adherence in comparison with this study and those carried out in countries with difficult access to health services.

Using the Tilburg scale to identify frailty, researchers found that non-frail older adults had a lower mean ( $4.1 \pm$ 2.0) associated with adherence to pharmacological treatment of hypertension, while frail people obtained a higher mean $(6.1 \pm 2.1)^{(17)}$. The Edmonton Frail Scale was used in this study, and the older adults with a good adherence had a lower mean $(5.50 \pm 3.12)$ compared to those who had an adherence considered to be bad $(6.82 \pm 2.878)$.

The literature presents conflicting data regarding the relationship between frailty and treatment adherence. A study carried out in Taiwan ${ }^{(22)}$ identified significantly worse adherence to treatment among non-frail patients, while researchers in Poland ${ }^{(17)}$ found the highest frailty scores among older adult patients, being considered a determining factor of less adherence to treatment. As in this study, there are publications which do not report a correlation between frailty and adherence ${ }^{(12,27)}$.

In a Kosmonautów outpatient clinic in Wroclaw, Poland, it was proven that there was a negative association between frailty and medication adherence in older adult hypertensive patients; however, the authors state that studies on the presence of frailty syndrome and adherence in patients with hypertension have not been conducted so far ${ }^{(17)}$.

Although there is no statistically significant relationship between adherence and frailty scores in Ribeirão Preto (SP), a study conducted in Poland points out that the early diagnosis of frailty and the difficulties associated with adherence to drug treatment by older adults allows inferring in the therapeutic conduct of those who are diagnosed with frailty and risk of cardiovascular complications due to untreated hypertension and then effectively plan interventions which will improve hypertension control ${ }^{(31)}$.
As this is a cross-sectional study, it was not possible to state that there was a causal inference between the associations of the studied variables, but the methodological option enabled the objective to be answered and the results found were compatible with studies carried out in several countries. Another limitation which must be considered is the lower chance of the participation of men over 65 years of age because they have shorter survival when compared to women of the same age, as pointed out by a Brazilian study ${ }^{(4)}$.

The theme is complex and involves several factors for non-adherence to medication treatment of hypertensive older adults; in this sense, the present study can contribute to the interdisciplinary practice of health professionals who provide care to older adults in different contexts of the health system and that they are aware of the factors which predispose them to poor adherence and frailty. Another way of stimulating adherence is the use of strategic actions in guidance groups carried out by health professionals and the inclusion of the family in the treatment in order to minimize difficulties, anxieties and promote patient adherence and safety in drug therapy.

\section{CONCLUSION}

The older adults in this study showed good adherence to antihypertensive treatment. Even though frailty did not result in a factor which interfered with adherence in this study, it is a syndrome which must be evaluated and monitored in older adults, as it is a risk predictor of cardiovascular diseases.

The nurse and the multidisciplinary team must have knowledge about the frailty syndrome, as it can be considered an independent and significant factor in low adherence to antihypertensive medication. Thus, considering that the higher the education of the older adult, the greater the contribution to good adherence to pharmacological treatment, adopting healthy habits can also contribute to better adherence of these people to the prescribed pharmacological treatments and a consequent improvement in blood pressure levels. Even though a direct relationship between frailty and adherence was not found, an early diagnosis of this syndrome can guide care which can prevent frailty in older adults and ensure adherence to therapeutic treatment.

\section{RESUMO}

Objetivo: Analisar a associação entre a adesão ao tratamento anti-hipertensivo e a síndrome da fragilidade no idoso hipertenso. Método: Estudo descritivo, transversal de abordagem quantitativa com idosos. A coleta de dados ocorreu entre novembro de 2017 e março de 2018, avaliando as informações sociodemográficos, a adesão ao tratamento anti-hipertensivo, os hábitos de vida e a fragilidade, por meio da Edmonton Frail Scale. Para a análise dos dados utilizou-se o teste de Kruskal Wallis e o teste de qui-quadrado, considerando o intervalo de confiança de $95 \%$ e o nível de significância $\mathrm{p}<0,05$. Resultados: Participaram do estudo 193 idosos. A média de idade foi de 80,94 (dp $\pm 7,17)$ anos, com predomínio do sexo feminino (72\%) e de viúvas $(43,5 \%)$. Os fatores que apresentaram associação com a adesão ao tratamento foram a pressão arterial diastólica, a escolaridade e o tempo que o idoso fuma ( $<<0,05)$. A fragilidade não apresentou associação com os níveis de adesão ao tratamento $(p=0,095)$. Conclusão: Não se constatou associação entre os escores de fragilidade e o controle da hipertensão arterial; entretanto, é fundamental na avaliação da adesão ao tratamento, o acompanhamento adequado e a assistência de enfermagem para reduzir os agravos da doença e o desenvolvimento da síndrome de fragilidade.

\section{DESCRITORES}

Idoso; Hipertensão; Adesão à Medicação; Fragilidade; Enfermagem Geriátrica.

\section{RESUMEN}

Objetivo: Analizar la asociación entre la adherencia al tratamiento antihipertensivo y el síndrome de la fragilidad en el adulto mayor con hipertensión. Método: Estudio descriptivo, transversal de abordaje cuantitativa con adultos mayores. La recolección de los datos ocurrió entre noviembre de 2017 y marzo de 2018, evaluando las informaciones sociodemográficas, la adherencia al 
tratamiento antihipertensivo, los hábitos de vida y la fragilidad, por medio de Edmonton Frail Scale. Para el análisis de los datos fueron utilizados el teste de Kruskal-Wallis y el teste de qui-quadrado. Para los dos testes el intervalo de confianza fue del $95 \%$ y el nivel de significancia p<0,05. Resultados: Participaron en el estudio 193 adultos mayores. La media de edad fue de 80,94 (dp \pm 7,17) años, con predominio del sexo femenino (72\%) y de viudas (43,5\%). Los factores que presentaron asociación con la adherencia al tratamientofueran la presión arterial diastólica, la escolaridad y el tiempo que el adulto mayor fuma $(\mathrm{p}<0,05)$. La fragilidad no presentó asociación con los niveles de adherencia al tratamiento $(p=0,095)$. Conclusión: No se ha constatado asociación entre los escores de fragilidad y el control de la hipertensión arterial; asímismo, es fundamental en la evaluación de la adherencia al tratamiento, del acompañamiento conveniente y la asistencia de enfermería para reducir la gravedad de la enfermedad y el desarrollo del síndrome de fragilidad.

\section{DESCRIPTORES}

Anciano; Hipertensión; Cumplimiento de la Medicación; Fragilidad; Enfermería Geriátrica.

\section{REFERENCES}

1. Cabral AC, Moura-Ramos M, Castel-Branco M, Fernandez-Llimos F, Figueiredo IV. Cross-cultural adaptation and validation of a European Portuguese version of the 8-item Morisky medication adherence scale. Rev Port Cardiol. 2018;37(4):297-303. DOI: 10.1016/j. repc.2017.09.017.

2. Silva EC, Martins MSAS, Guimarães LV, Segri NJ, Lopes MAL, Espinosa MM. Prevalência de hipertensão arterial sistêmica e fatores associados em homens e mulheres residentes em municípios da amazônia legal. Rev Bras Epidemiol 2016;19(1):38-51. DOI: 10.1590/19805497201600010004

3. Moreira JPL, Moraes JR, Luiz RR. A prevalência de hipertensão arterial sistêmica autorreferida nos ambientes urbano e rural do Brasil: um estudo de base populacional. Cad Saúde Pública 2013;29(1):62-72. DOI: http://dx.doi.org/10.1590/S0102-311X2013000100008.

4. Menezes TN, Oliveira ECT, Fischer MATS, Esteves GH. Prevalência e controle da hipertensão arterial em idosos: um estudo populacional. Rev Port Saúde Pub. 2016;34(2):117-24. DOI: http://dx.doi.org/10.1016/j.rpsp.2016.04.001

5. Malachias MVB, Plavnik FL, Machado CA, Malta D, Scala LCN, Fuchs S. $7^{\text {a }}$ Diretriz Brasileira de Hipertensão Arterial: Capítulo 1 - Conceituação, Epidemiologia e Prevenção Primária. Arq Bras Cardiol. 2016;107(3 Suppl 3):1-6. DOI: http://dx.doi.org/10.5935/ abc. 20160151

6. Picon RV, Fuchs FD, Moreira LB, Fuchs SC. Prevalence of hypertension among elderly persons in urban Brazil: a systematic review with meta-analysis. Am J Hypertens. 2013;26(4):541-8. DOI: 10.1093/ajh/hps076

7. Alves ACP, Nascimento ACG, Angélica Almeida IM, Costa FBC, Oliveira CJ. Ações de enfermagem ao paciente com hipertensão arterial que apresenta o diagnóstico "falta de adesão". Rev Enferm UFPE On line. 2015;9 Supl. 2:806-13. DOI: 10.5205/reuol.6391-62431-2ED.0902supl201505

8. Williams B, Mancia G, Spiering W, Rosei EA, Azizi M, Burnier MI, et al. 2018 ESH/ESC guidelines for the management of arterial hypertension: the Task Force for the management of arterial hypertension. Eur Heart J. 2018;39(33):3021-104. DOI: https://doi.org/10.1093/ eurheartj/ehy339

9. World Health Organization. A global brief on hypertension: silent killer, global public health crisis [Internet]. Geneva: WHO; 2013 [cited 2018 Nov 12]. Available from: https://apps.who.int/iris/bitstream/handle/10665/79059/WHO_DCO_WHD_2013.2_eng.pdf?sequence=1

10. Corrao G, Rea F, Ghirardi A, Soranna D, Merlino L, Mancia G. Adherence with antihypertensive drug therapy and the risk of heart failure in clinical practice. Hypertension. 2015;66(4):742-9. DOI: https://doi.org/10.1161/HYPERTENSIONAHA.115.05463

11. Rajpura J, Nayak R. Medication adherence in a sample of elderly suffering from hypertension: evaluating the influence of illness perceptions, treatment beliefs, and illness burden. J Manag Care Pharm. 2014;20(1):58-65. DOI: https://doi.org/10.18553/jmcp.2014.20.1.58

12. Morley JE, Vellas B, van Kan GA, Anker SD, Bauer JM, Bernabei R, et al. Frailty consensus: a call to action. J Am Med Dir Assoc. 2013;14(6):392-7. DOI:10.1016/j.jamda.2013.03.022

13. Rockwood K, Howlett SE, MacKnight C, Beattle BL, Bergman H, Hébert R, et al. Prevalence, attributes and outcomes of fitness and frailty in community-dwelling older adults: report from the Canadian Study of health and aging. J Gerontol A Biol Sci Med Sci. 2004;59(12):1310-7. DOI: https://doi.org/10.1093/gerona/59.12.1310

14. Rockwood K, Mitnitski A. Frailty in relation to the accumulation of deficits. J Gerontol A Biol Sci Med Sci. 2007;62(7):722-7. DOI: https:// doi.org/10.1093/gerona/62.7.722

15. Rolfson DB, Majumdar SR, Tsuyuki RT, Tahir A, Rockwood K. Validity and reliability of the Edmonton Frail Scale. Age Ageing. 2006;35(5):526-9. DOI: 10.1093/ageing/af I023

16. Nunes DP, Duarte YAO, Santos JLF, Lebrão ML. Rastreamento de fragilidade em idosos por instrumento autorreferido. Rev Saúde Pública. 2015;49:2. DOI: http://dx.doi.org/10.1590/S0034-8910.2015049005516

17. Jankowska-Polańska B, Zamęta K, Uchmanowicz I, Szymańska-Chabowska A, Morisky D, Mazur G. Adherence to pharmacological and non-pharmacological treatment of frail hypertensive patients. Am J Geriatr Cardiol. 2018;15(2):153-61. DOI: 10.11909/j. issn.1671-5411.2018.02.002

18. Jankowska-Polańska B, Dudek K, Szymanska-Chabowska A, Uchmanowicz I. The influence of frailty syndrome on medication adherence among elderly patients with hypertension. Clin Interv Aging. 2016; 11: 1781-1790. DOI: 10.2147/CIA.S113994

19. Bloch KV, Melo AN, Nogueira AR. Prevalência da adesão ao tratamento anti-hipertensivo em hipertensos resistentes e validação de três métodos indiretos de avaliação da adesão. Cad Saúde Pública. 2008;24(12):2979-84. DOI: http://dx.doi.org/10.1590/S0102311 X2008001200030.

20. Lee JY, Kusek JW, Greene PG, Bernhard S, Norris K, Smith D, et al. Assessing medication adherence by pill count and electronic monitoring in the African American Study of Kidney Disease and Hypertension (AASK) Pilot Study. Am J Hypertens. 1996;9(8):719-25. DOI: https:// doi.org/10.1016/0895-7061(96)00056-8 
21. Fabrício-Wehbe SCC, Schiaveto FV, Vendrusculo TRP, Haas VJ, Dantas RAS, Rodrigues RAP. Cross-cultural adaptation and validity of the "Edmonton Frail Scale - EFS" in a Brazilian elderly sample. Rev Latino Am Enfermagem. 2009;17(6):1043-9. DOI: http://dx.doi.org/10.1590/ S0104-11692009000600018.

22. Chao CT, Huang JW; COGENT (Cohort of Geriatric Nephrology in NTUH) study group. Geriatric syndromes are potential determinants of the medication adherence status in prevalent dialysis patients. Peer J. 2016;14:e2122. DOI: 10.7717/peerj.2122. ECollection 2016

23. Adidja NM, Agbor VN, Aminde JA, Ngwasiri CA, Ngu KB, Aminde LN. Non-adherence to antihypertensive pharmacotherapy in Buea, Cameroon: a cross-sectional community-based study. BMC Cardiovasc Disord. 2018;18(1):150. DOI: http://doi.org/10.1186/s12872018-0888-z

24. Arruda DCJ, Eto FN, Velten APC, Morelato RL, Oliveira ERA. Fatores associados a não adesão medicamentosa entre idosos de um ambulatório filantrópico do Espírito Santo. Rev Bras Geriatr Gerontol. 2015;18(2):327-37. DOI: http://dx.doi.org/10.1590/18099823.2015.14074.

25. Cezar-Vaz MR, Bonow CA, Abreu DPG, Vaz JC, Mello MCVA, Xavier DM. Rural workload and factors associated with the use of medication by elderly people. Rev Esc Enferm USP. 2018; 52:e03374. DOI: http://dx.doi.org/10.1590/s1980-220x2017048303374

26. Ferreira RA, Barreto SM, Giatti L. Hipertensão arterial referida e utilização de medicamentos de uso contínuo no Brasil: um estudo de base populacional. Cad Saúde Pública. 2014;30(4):815-26. DOI: http://dx.doi.org/10.1590/0102-311X00160512

27. Asgedom SW, Atey TM, Desse TA. Antihypertensive medication adherence and associated factors among adult hypertensive patients at Jimma University Specialized Hospital, southwest Ethiopia. BMC Res Notes. 2018;11:27. DOI: https://doi.org/10.1186/s13104-018-3139-6

28. Andrade SSA, Stopa SR, Brito AS, Chueri PS, Szwarcwald CL, Malta DC. Prevalência de hipertensão arterial autorreferida na população brasileira: análise da Pesquisa Nacional de Saúde, 2013. Epidemiol Serv Saúde. 2015;24(2):297-304. DOI: http://dx.doi.org/10.5123/ S1679-49742015000200012.

29. Freitas JGA, Sylvia EON, Celmo CP. Adesão ao tratamento farmacológico em idosos hipertensos: uma revisão integrativa da literatura. Rev Soc Bras Clin Med. 2015;13(1):75-84.

30. Lima DBS, Moreira TMM, Borges JWP, Rodrigues MTP. Associação entre adesão ao tratamento e tipos de complicações cardiovasculares em pessoas com hipertensão arterial. Texto Contexto Enferm. 2016;25(3):e0560015. DOI: http://dx.doi.org/10.1590/010407072016000560015

31. Uchmanowicz I, Jankowska-Polańska B, Łoboz-Rudnicka M, Gobbens R. Cross-cultural adaptation and reliability testing of the Tilburg frailty indicator for optimizing care of Polish patients with frailty syndrome. Clin Interv Aging. 2014;9:997-1001. DOI https://doi. org/10.2147/CIA.S64853

Financial support:

Conselho Nacional de Desenvolvimento Científico e Tecnológico (CNPq). Process no. 305565/2016-8. 